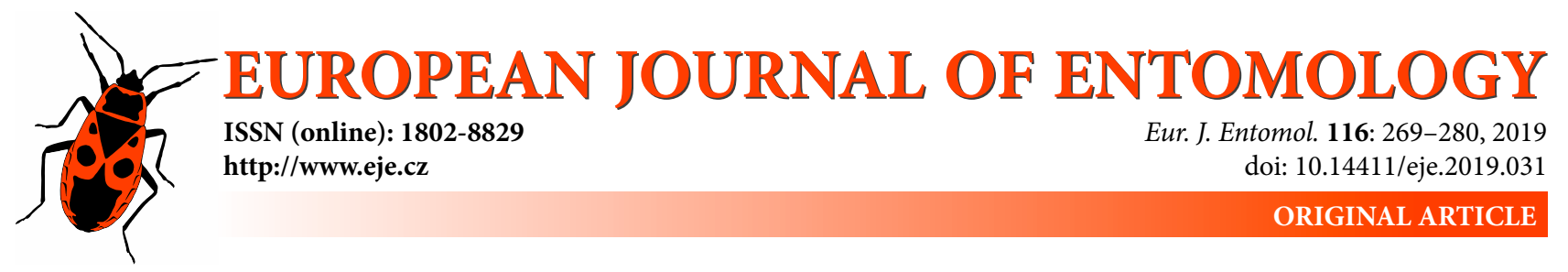

\title{
Biometry of the large dragonfly Anax imperator (Odonata: Aeshnidae): A study of traits from larval development to adults
}

\author{
MARCeau MINOT ${ }^{1}$, MickaËL LE GALL² ${ }^{\text {and AuRÉlie HUSTÉ }}{ }^{1}$ \\ ${ }^{1}$ Université de Rouen - ECODIV, Bat Blondel, Place Emile Blondel, Mont-Saint-Aignan 76821, France; \\ e-mails: marceau.minot1@univ-rouen.fr, aurelie.huste@univ-rouen.fr \\ ${ }^{2}$ IRSTEA, UR RIVERLY, Centre de Lyon - Villeurbanne, 69625 Villeurbanne Cedex, France; e-mail: mickael.legall1@gmail.com
}

Key words. Odonata, Aeshnidae, Anax imperator, body length, body mass, larval rearing, sexual size dimorphism, traits

\begin{abstract}
Insect larval development affects adult traits but the biometric relationships are usually poorly understood, including large odonates. In this study, measurements of morphological traits of larvae, exuviae and adults of Anax imperator were recorded. They were used to investigate the effects of early development on adult morphology. Results showed an increase in larval length during the final instar and the length of its exuviae significantly exceeded that of the larva. Length and body mass of teneral adults were strongly related to the length of their exuviae. Adult males were significantly longer than adult females, while both had the same body mass at emergence. Length of teneral adults was negatively related to the date of emergence in both sexes. During maturation, body mass of males only increased slightly whereas that of females increased greatly. Mature specimens were also significantly longer than teneral individuals. Body mass of mature males and length of mature females were both associated with the date of capture. Wing length did not differ between sexes or from data available from Great Britain. This study underscores the importance of taking into account larval growth in order to better understand the adult traits of odonates.
\end{abstract}

\section{INTRODUCTION}

Phenotypic traits are widely used in studies on the performance of plants and animals in terms of survival or mating success (McGill et al., 2006; Violle et al., 2007; Lailvaux \& Husak, 2014). In the last few decades, trait-based approaches have been used in studies on populations, communities and ecosystems (Enquist et al., 2015; Kremer et al., 2017). Multivariate analyses and complex models now enable the prediction, among others, of species or population distributions along environmental gradients (Litchman et al., 2010; Santos et al., 2017). Body size can be used as a proxy for organismal fitness (Blanckenhorn, 2000) and Bergmann's Rule is widely used to link body size to both temperature and latitudinal gradients (Watt et al., 2010; Faurby \& Araújo, 2017). Originally developed for warmblooded animals, this ecological concept was extended to many invertebrate taxa, including insects (Honěk, 1993; Arnqvist et al., 1996; Chown \& Gaston, 2010). In odonates, body size and other traits, such as voltinism (i.e. number of generations per year), are driven by temperature (Corbet et al., 2006; Zeuss et al., 2017). Latitudinal gradients were significantly associated with the size of eggs, larvae and adults for Zygoptera (De Block \& Stoks, 2003; Johansson, 2003; Stoks \& De Blok, 2011; Sniegula et al., 2016). Moreover, body mass and size are also associated with female fertility and male mating success in territo- rial species (Anholt et al., 1991; Grether, 1996; SerranoMeneses et al., 2007; Samejima \& Tsubaki, 2010). Usually, in odonates, large individuals appear to be generally fitter (Sokolovska et al., 2000), but this trend is probably counterbalanced by stabilizing selection (Thompson \& Fincke, 2002). For instance, the longer larval development necessary to produce large adults also results in higher predation risks (Waller \& Svensson, 2017). Previous studies focused mostly on Zygoptera and little is known about selection pressures that constrain the development of the traits of large dragonflies from larval stages to the emergence of adults (Stoks \& Córdoba-Aguilar, 2012).

In the cosmopolitan genus Anax, larvae measure up to 70 $\mathrm{mm}$ (Suhling et al., 2014) and are commonly abundant in ponds (Calvert, 1934; Corbet, 1955). They are easy to rear, making them a good model for predator behaviour and diet in ecological studies (Folsom \& Collins, 1984; Bergelson, 1985; Blois, 1985; Blois \& Cloarec, 1985; Blois-Heulin, $1990 \mathrm{a}, \mathrm{b})$. They are also often used to investigate the effect of predators on prey traits and community assemblages (Stav et al., 2000; Stoks \& McPeek, 2003; McCauley, 2005; Relyea, 2012; Klecka \& Boukal, 2013). Adults are robust and the males of several species are territorial (Corbet, 1999). Anax imperator Leach, 1815 is the largest dragonfly species in occidental Europe and is very commonly found in large waterbodies with vegetation (Heidemann 
\& Seidenbusch, 2002; Brochard et al., 2012). Its distribution ranges from South Africa to Sweden (Dijkstra, 2006; Tarboton \& Tarboton, 2015). Comparisons of populations at different latitudes can be carried out, since this species does not migrate (Corbet, 1999). Differences in voltinism are also reported. For instance, in Europe, southern populations are able to complete two generations per year (i.e. bivoltine), while most northern populations need two years to complete a life cycle (i.e. semivoltine; Corbet, 2006). Aside from major studies of this species in England (Corbet, 1955, 1957), there is little data on its larval traits (Portmann, 1921; Robert, 1958; Serrano-Meneses et al., 2007; Lamelas-López et al., 2017). Studies on the whole life cycle or the relationships between larval and adult traits of large odonates would provide a better understanding of the carry-over effects in terms of larval development conditions and adult fitness (Stoks \& Córdoba-Aguilar, 2012). Unfortunately, data on the body size or mass of adult $A$. imperator are scarce (but see Serrano-Meneses et al., 2007). Indeed, young imagines of this species are difficult to study, since they emerge mostly during the night and take flight at dawn (Corbet, 1957). After maturation adults fly very fast and often stay away from the banks of ponds, behaviour that makes them hard to catch. Nevertheless, identifying variations in larval development within and between voltinism classes and dispersal events of adults along latitudinal gradients could be a key to understanding the maintenance of populations and colonization in different parts of their distributions. For example, the migratory species Anax junius (Drury, 1773) is able to fly several hundreds of kilometers during its life time (Wikelsky et al., 2006), which results in competition between different cohorts of migrants and resident populations in some places (Crumrine, 2010).

With the present increasing landscape fragmentation (Fardila et al., 2017), physical barriers to dispersal, such as main roads or cities, are obstacles to establishment, growth and a posteriori maintenance of populations (Haddad et al., 2015). Moreover, dispersal is related to intrinsic traits of species that determine their capacity for moving. For instance, wingspan can be used as a proxy of dispersal ability in butterflies (Burke et al., 2011; Sekar, 2012; Slade et al., 2013). However, there is no relationship between wing shape and dispersal in other insects like Trichoptera (Lancaster \& Downes, 2017). There is no similar work on the relationships between traits and dispersal for odonates, but the ranges of several species of Zygoptera are thought to be correlated with wing size (Rundle et al., 2007; Swaegers et al., 2014). Besides these interspecific comparisons, there is little evidence of intraspecific associations between traits, such as wingspan or body size, and dispersal capacity (Taylor \& Merriam, 1995; Conrad et al., 2002) or migration (Michiels \& Dhont, 1989).

In this study, the associations between growth traits in the different life stages of the dragonfly $A$. imperator were investigated. Using measurements of larvae and their exuviae, we first tested the effect of preservation and compared the larval growth of the different sexes and stadia, with an

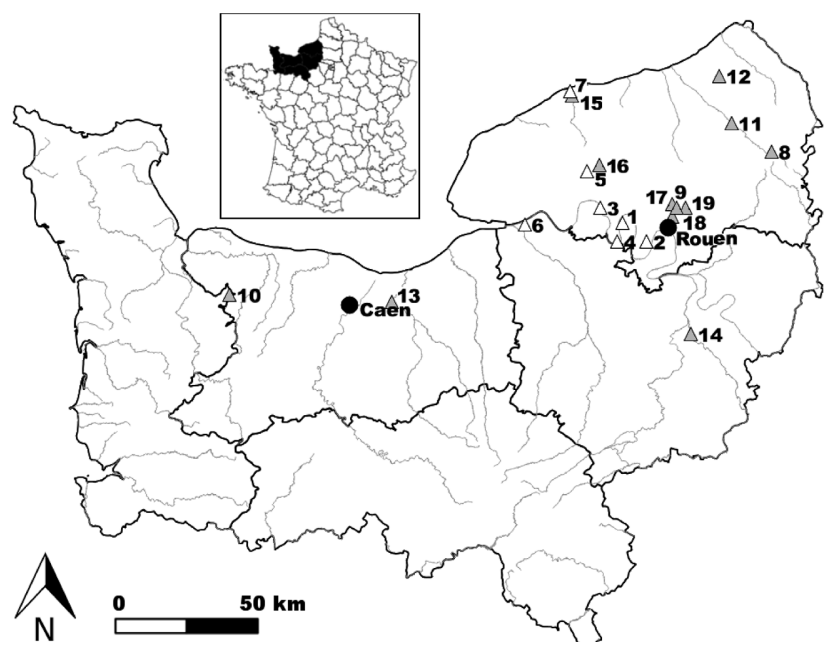

Fig. 1. Map of the study area in Normandy (France) showing the locations of the ponds sampled in 2014 (white triangles) and 2017 (grey triangles).

emphasis on the metamorphosis that occurs during the last larval instar. Then, the teneral and mature adults were measured and the relationship between larval and adult traits was investigated. The effect of seasonality on adult traits was also studied to test the hypothesis that emerging adults of $A$. imperator are smaller at the end of the season. At each stage of life, male and female traits were compared in order to investigate Sexual Size Dimorphism (SSD). Finally, the association between body size of larvae, wing length of adults, and latitude is discussed.

\section{MATERIALS AND METHODS}

\section{Ponds sampled and methods}

Normandy is a region located in north-western France which covers $5 \%$ of the country (Fig. 1). With 3.3 million inhabitants and a density of 112 inhabitants per $\mathrm{km}^{2}$ (data from 2016; www. insee.fr), this area is moderately populated. Landscape consists mostly of farmland, pastures, cities, woodland and low rolling hills. Nineteen ponds were selected based on their accessibility and suitability as a habitat for larvae of $A$. imperator (e.g. large and sunny ponds with abundant vegetation). A total of 345 larvae and 143 exuviae were collected in 2014 and 2017 (Fig. 1; Table $1)$.

Of these larvae, 211 were collected in 2014 from 7 ponds and 30 in 2017 from 5 ponds over the period May-July and preserved in pure ethanol. They were collected using a $25 \times 25 \mathrm{~cm}$ kick-net with a $0.5 \mathrm{~mm}$ mesh size. Between 11 May and 13 June 2017, another 104 larvae were collected from 5 ponds using $50 \times 50 \mathrm{~cm}$ nets with $6 \mathrm{~mm}$ and $12 \mathrm{~mm}$ mesh sizes, and reared individually (Fig. 1; Table 1). Using nets with a larger mesh was a more efficient way collecting only last instar larvae. In both years, larvae were sampled by making broad eight-shaped movements of the net in the vegetation, in particular that of floating macrophytes, such as Potamogeton sp. or Ranunculus sp., and of stands of helophytes, such as Carex sp. and Juncus sp. Exuviae were collected in 2014 only from 4 of the 7 ponds used for sampling larvae (Table 1). They were collected from the vegetation on the banks of the ponds and all were preserved in pure ethanol.

In order to compare the traits of teneral adults that emerged from reared larvae with those of mature individuals, 51 flying adults (34 males and 17 females) were caught at 4 ponds and in 
Table 1. Ponds sampled and counts of the different odonate stages collected. ID refers to the numbers on Fig. 1.

\begin{tabular}{|c|c|c|c|c|c|c|c|}
\hline ID & Year & Purpose & Site & Larvae & Exuviae & Adults & Coordinates WGS84 (N,E) \\
\hline 1 & 2014 & Material stored & Anneville-Ambourville & 31 & 3 & 0 & $49.458,0.876$ \\
\hline 2 & 2014 & Material stored & Mare Epinay & 5 & 0 & 0 & $49.404,0.987$ \\
\hline 3 & 2014 & Material stored & ND-de-Bliquetuit & 63 & 0 & 0 & $49.502,0.770$ \\
\hline 4 & 2014 & Material stored & Jumièges & 65 & 15 & 0 & $49.402,0.852$ \\
\hline 5 & 2014 & Material stored & Valliquerville & 2 & 1 & 0 & $49.609,0.704$ \\
\hline 6 & 2014 & Material stored & Marais Vernier & 42 & 0 & 0 & 49.4450 .426 \\
\hline 7 & 2014 & Material stored & Veulettes sur mer & 3 & 124 & 0 & $49.852,0.609$ \\
\hline 8 & 2017 & Material stored & Beaussault & 11 & 0 & 0 & $49.682,1.555$ \\
\hline 9 & 2017 & Material stored & Métropole de Rouen (a) & 7 & 0 & 0 & $49.480,1.102$ \\
\hline 10 & 2017 & Material stored & Forêt de Cerisy & 7 & 0 & 0 & $49.199,-0.912$ \\
\hline 11 & 2017 & Material stored & Mesnières en Bray & 1 & 0 & 0 & $49.764,1.366$ \\
\hline 12 & 2017 & Material stored & St Ouen sous Bailly & 4 & 0 & 0 & $49.905,1.305$ \\
\hline 9 & 2017 & Larvae reared & Métropole de Rouen (a) & 44 & 0 & 0 & $49.480,1.102$ \\
\hline 13 & 2017 & Larvae reared & Bures sur Dives & 1 & 0 & 0 & $49.200,-0.169$ \\
\hline 14 & 2017 & Larvae reared & Heudreville & 42 & 0 & 0 & $49.133,1.197$ \\
\hline 15 & 2017 & Larvae reared & Paluel & 15 & 0 & 0 & $49.835,0.625$ \\
\hline 16 & 2017 & Larvae reared & Yvetot & 2 & 0 & 0 & $49.629,0.761$ \\
\hline 9 & 2017 & Adult measurements & Métropole de Rouen (a) & 0 & 0 & 27 & $49.480,1.102$ \\
\hline 17 & 2017 & Adult measurements & Métropole de Rouen (b) & 0 & 0 & 19 & $49.484,1.099$ \\
\hline 18 & 2017 & Adult measurements & Métropole de Rouen (c) & 0 & 0 & 4 & $49.469,1.093$ \\
\hline 19 & 2017 & Adult measurements & Métropole de Rouen (d) & 0 & 0 & 1 & $49.481,1.120$ \\
\hline \multicolumn{3}{|c|}{ TOTAL } & & 345 & 143 & 51 & \\
\hline
\end{tabular}

their surroundings between 17 June and 29 August 2017 (Fig. 1; Table 1).

\section{Rearing of larvae}

To avoid feeding them, last instar larvae were first placed into small wire cages close to the bank of a single pond (pond 9; see Table 1). A mesh width of $5 \mathrm{~mm}$ allowed small invertebrates to enter and serve as prey but prevented $A$. imperator larvae from escaping, since the minimal head width of last instar larvae is larger than $8 \mathrm{~mm}$. When they reached the fifth stage of metamorphosis (Fig. A1) or later, larvae were then reared in outdoor cages near the laboratory. At this stage, the larval prementum starts to retract and larvae stop feeding (Corbet, 1957).

After sex determination, larvae were placed in individual 1.8 litre polypropylene boxes (La Bovida, CARTY) and reared until emergence. Each box was filled with water to a depth of about 7 $\mathrm{cm}$. Two $45 \mathrm{~cm}$ bamboo sticks wrapped with fine string to improve adherence of larval claws were placed in each box to provide supports on which larvae could climb above the water level and moult to the adult stage. Wire cages were built out of $5 \mathrm{~mm}$ metallic mesh and used to keep adults separated after emergence. One male and one female were placed together into each cage. Just after emergence, adults were sexed and their exuviae collected. Of the 104 individuals initially sampled, 87 were successfully reared to emergence and 78 were measured and weighed.

\section{Measurements of the traits of larvae and teneral adults}

Larval instars were classified following Benke (1970) and Ferreras-Romero \& Corbet (1999) using head width and wing pad length, and categorized as follows: F0 (final instar), F-1 (penultimate instar), F-2 and F-3. In order to accurately monitor larval development during the days prior to ecdysis, F0 larvae were categorized as in one of 6 stages of metamorphosis (M1 to M6) according to Corbet (1957). These stages were determined based on changes in eye shape, wing buds and labium (Figs A1 and A2). Sex was determined by the presence or absence of gonapophyses on the $9^{\text {th }}$ abdominal segment. This structure is apparent in larvae, exuviae and adult females.

Total length, head width and wing pad length of all larvae and exuviae preserved in ethanol were measured using a GENERAL Metric Dial Caliper under a Leica MZ6 stereomicroscope. When the body of a specimen was bent, its total length measurement was not included in the analyses. In the case of reared larvae, they were placed on plasticized graph paper and photographed. Total length was then read from the picture with a precision of 0.5 $\mathrm{mm}$. Just after emergence, reared tenerals were measured using calipers to the nearest $0.1 \mathrm{~mm}$ and weighed on a DENVER MXX612 scale to the nearest $0.01 \mathrm{~g}$. Exuviae of reared larvae were also measured before storage in absolute ethanol.

\section{Measurements of the traits of mature adults}

Mature adults were put into a paper envelope and weighed in the field using an OHAUS Traveler TA152 scale. Total length and right hind wind length were also measured with calipers.

More details on measurements of larvae and adults are available in Fig. A3.

\section{Data analyses}

Means are given \pm standard deviation (SD). All statistical analyses were performed using R 3.4.2 software (R Core Team, 2017).

To identify larval instars, head width was plotted against wing pad length. Each cloud of points was then distinguished graphically. As M5 in A. imperator lasts only one or two days and was represented by only a few specimens in the sample, metamorphosis stages 5 and 6 were pooled.

Some previous studies report an effect of ethanol preservation on body mass of aquatic macroinvertebrates (Leuven et al., 1985; Méthot et al., 2012). However, little is known about changes in length caused by this mode of preservation of benthic macroinvertebrates (e.g. no constant shrinking of larvae of Ephemeroptera in concentrations of ethanol ranging from $70 \%$ to $95 \%$ : Heise et al., 1988; von Schiller \& Solimini, 2005). An effect of this mode of preservation is reported for the dragonfly A. junius, but without statistical assessment (Calvert, 1943). Therefore, using data from specimens preserved in different ways may introduce a real bias into the results.

In this study on A. imperator, two groups of larvae were used. One group was composed of live larvae and the other of dead larvae preserved in pure ethanol. Effects of ethanol preservation, metamorphosis stage and their interaction on total length of last instar larvae were tested. Since assumptions of normality and ho- 
moscedasticity of data were not verified, a non-parametric twoway analysis of variance, the Scheirer-Ray-Hare test, was performed using the "rcompanion" R package (Mangiafico, 2017). Length of F0 larvae preserved in ethanol $(45.1 \pm 3.3 \mathrm{~mm})$ was not significantly different from that of live larvae $(46.3 \pm 1.9 \mathrm{~mm}$; Scheirer-Ray-Hare test: $\mathrm{H}=2.03, \mathrm{P}=0.15, \mathrm{df}=1$ ) and this was the case for all the stages of metamorphosis (Scheirer-Ray-Hare test: interaction $\mathrm{H}=3.11, \mathrm{P}=0.53, \mathrm{df}=4$ ). For further analyses, all larvae were therefore included regardless of the method of preservation.

A Scheirer-Ray-Hare test was used to determine the association between sex, instar and their interaction on total length of both larvae and exuviae. Exuviae of reared individuals were excluded from this analysis to ensure independency of the data for the different instars. A comparison between mean lengths of reared final instar larvae at capture and mean lengths of their corresponding exuviae after emergence was also done using a paired Student's t-test after verifying the normality of the data.

Analyses of body mass and length of teneral adults were first performed using mixed GLMM models in order to consider a potential random effect of ponds. However, the estimated variance explained by the random effect was particularly weak $\left(1.10^{-8}\right)$, suggesting that the intercept of the model for the population (i.e. fixed part) did not change when each pond was considered separately. Therefore, a standard multiple regression was used to investigate the effect of total length of larvae, total length of exuviae, sex, date of emergence, sampling pond and rearing duration on body mass of teneral adults. Final model was selected based on Akaike Information Criterion (AIC) using a backward model selection. A generalized least squares (GLS) regression was used to investigate the effect of total length of larvae, total length of exuviae, sex, sampling pond, date of emergence and rearing duration on length of teneral adults. This analysis was used in order to correct for the observed heterogeneity in the residual variance between sexes (Zuur et al., 2009, 2015) and was done using the "nlme" R package (Pinheiro et al., 2018). A pseudo adjusted $\mathrm{R}^{2}$ was assessed using the "rcompanion" $\mathrm{R}$ package (Mangiafico, 2017). Normality and homoscedasticity of residuals were systematically tested after regressions.

Effects of sex, age (i.e. teneral or mature) and their interaction were first tested on the total length of adults and then on their hind wing length, using a two-way analysis of variance (ANOVA), after verifying normality and homoscedasticity of the data. A Scheirer-Ray-Hare test was used to investigate effects of sex, age and their interaction on the total body mass of adults. When necessary, post-hoc tests were performed after ANOVAs and Scheirer-Ray-Hare tests. Polynomial regressions were used to investigate the effect of the date of capture on the total length and body mass of mature individuals of each sex. Models were selected based on AIC using backward selection.

Finally, adult hind wing lengths were compared with values from the database of morphological and geographical traits of the British odonates (Powney et al., 2014) using Student's t-tests.

\section{RESULTS}

\section{Larval stages}

A plot of wing pad length against head width revealed 5 clouds of points, each of which is associated with a particular larval instar (Fig. 2). Frequency histogram of head widths indicate distinct modes for the 4 last instars. Frequency histogram of wing pad lengths indicate very clear modes for F0 and F-1, but does not discriminate between the smaller instars. Threshold values for head width and

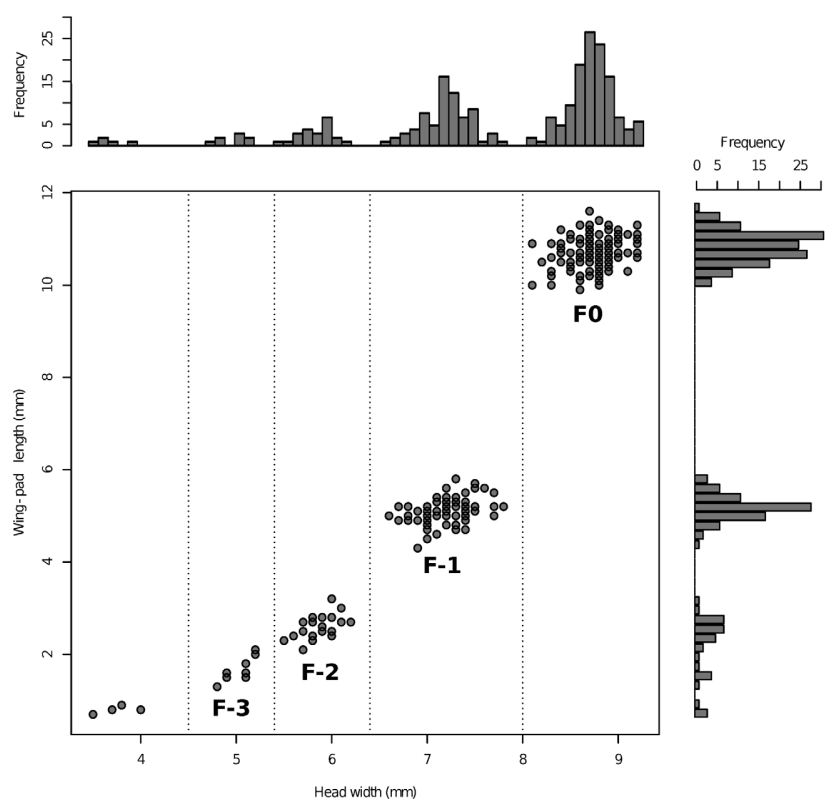

Fig. 2. Plot of larval wing pad length against head width for larvae of $A$. imperator $(\mathrm{n}=241)$. Histograms show the frequency of measurements. Peaks and valleys were used to identify larval instars. Extrapolated threshold values for head width are represented by dotted vertical lines.

wing pad length that were defined graphically for $A$. imperator in Normandy are presented in Table 2.

There was a significant difference in total length between each instar from F-4 to exuviae and even within the different stages of metamorphosis of F0 larvae (Scheirer-RayHare test: $\mathrm{H}=240, \mathrm{P}<0.001$, df $=9$; Fig. 3). Female larvae $(45.3 \pm 7.2 \mathrm{~mm})$ were significantly longer than male larvae $(41.1 \pm 9.4 \mathrm{~mm}$; Scheirer-Ray-Hare test: $\mathrm{H}=19.7$, $\mathrm{P}<0.001, \mathrm{df}=1)$ and there was no significant interaction between sex and stage of metamorphosis (Scheirer-RayHare test: $\mathrm{H}=0.884, \mathrm{P}=0.999, \mathrm{df}=8$ ).

In order to compare the length of the reared larvae and their exuviae, the measurements of larvae between M3 and M6 were pooled. Stages of metamorphosis M1 and M2 could not be included in this analysis since they were significantly different in length from stages M3 to M6 (Fig. $3)$. Exuviae $(51.1 \pm 2.4 \mathrm{~mm})$ were significantly longer than their corresponding last instar larvae $(45.9 \pm 1.8 \mathrm{~mm}$; Paired Student's t-test: $\mathrm{t}=8.68, \mathrm{P}<0.001, \mathrm{df}=25$ ).

\section{Adult traits}

Body mass of teneral adults was significantly associated with the total length of their exuviae and duration of larval development (Table 3, Fig. 4a, b). Total length of teneral adults was significantly associated with total length of exuviae, sex and date of emergence (Table 3, Fig. 5a, b).

Table 2. Thresholds identified graphically for head-width and wing pad length within the dataset of this study and used to separate larval instars. Values are in $\mathrm{mm}$.

\begin{tabular}{lcccc}
\hline & F-3 & F-2 & F-1 & F0 \\
\hline Head-width & $4.5-5.4$ & $5.4-6.4$ & $6.4-8$ & $8-9.5$ \\
Wing pad length & NA & NA & $4-6$ & $9.5-12$ \\
\hline
\end{tabular}




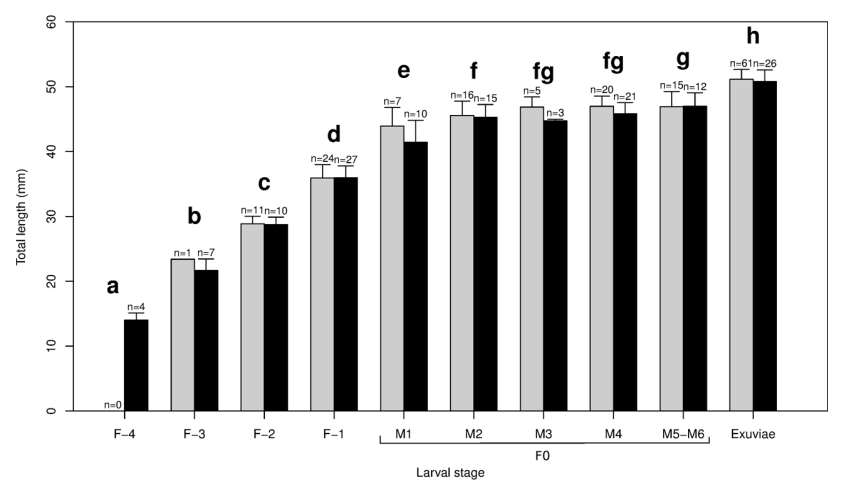

Fig. 3. Total length of female (in grey) and male (in black) collected larvae (F-4 to exuviae) pooled with reared larvae (M1 to M6). Al measurements were for different individuals and exuviae of reared larvae were not included. Letters show significant differences in post-hoc analyses $(\alpha=0.05)$. Values plotted are means + SD.

Mature individuals $(77.1 \pm 2.4 \mathrm{~mm})$ were significantly longer than teneral individuals $(74.0 \pm 3.0 \mathrm{~mm})$ and males $(77.2 \pm 2.3 \mathrm{~mm})$ were throughout adult life significantly longer than females $(72.9 \pm 2.3 \mathrm{~mm})$ (Table 4; Fig. 6a). There was no significant difference in hind wing length associated with sex or age and no interaction between these factors (Table 4; Fig. 6b). The comparison of our data (49.8 $\pm 1.5 \mathrm{~mm})$ with that collected in Great Britain $(50.2 \pm 1.1$ $\mathrm{mm})$ revealed no significant difference $(\mathrm{t}=1.35, \mathrm{P}=0.191$, $\mathrm{df}=22.57$ ) in the length of the right hind wing. There was an association between sex, age and their interaction on body mass (Table 4; Fig. 6c). Mature individuals were sig- nificantly heavier $(1.06 \pm 0.16 \mathrm{~g})$ than teneral adults $(0.90$ \pm 0.08 ; Table 4; Fig. $6 \mathrm{c}$ ). While there was no significant difference in body mass between teneral males and teneral females (Table 4; Fig. 6c), mature females $(1.26 \pm 0.09$ g) were significantly heavier than mature males $(0.97 \pm$ 0.07 g; Table 4; Fig. 6c).

The body mass of mature males was significantly associated with the date they were sampled (Table 5) and the theoretical maximum was predicted to occur on Julian Day 216 (04/08/2017; Fig. 7a). Total length of females was also significantly associated with the date they were sampled (Table 5) and the theoretical maximum was predicted to occur on Julian Day 213 (01/08/2017; Fig. 7b). No significant relationships were found between date of sampling and female body mass or male total length.

\section{DISCUSSION}

Carry-over effects can be defined as changes in measurable traits induced by environmental conditions that persist over seasons or subsequent stages of life (Harrison et al., 2011; Pechenik, 2012; Stoks \& Córdoba-Aguilar, 2012). In Odonata, hatching date and larval conditions have a significant effect on adult traits, at least in damselflies (Stoks \& Córdoba-Aguilar, 2012, Arambourou, 2017; Tüzün \& Stoks, 2018). However, more information is necessary to decipher mechanisms that are responsible for carry-over effects between larval and adult stages, especially in large odonates. Based on a set of morphological measurements,

Table 3. Results of the regression analyses of the predictors of body mass and total length of teneral adults of Anax imperator.

\begin{tabular}{lcrl}
\hline Model summary & Selected variable & Estimate \pm SE & Estimate $p$-value \\
\hline Body mass of teneral adults & & \\
$\quad \mathrm{df}=42$ & Total length of exuviae & $0.028 \pm 0.006$ & $<0.001$ \\
$\quad \begin{array}{l}\text { Adjusted } \mathrm{R}^{2}=0.336 \\
\text { Total length of teneral adults }\end{array}$ & Rearing duration & $-0.003 \pm 0.001$ & 0.021 \\
$\mathrm{df}=43$ & Total length of exuviae & $0.860 \pm 0.122$ & $<0.001$ \\
Pseudo adjusted $\mathrm{R}^{2}=0.792$ & Sex & $4.794 \pm 0.507$ & $<0.001$ \\
& Date of emergence & $-0.039 \pm 0.017$ & 0.028 \\
\hline
\end{tabular}
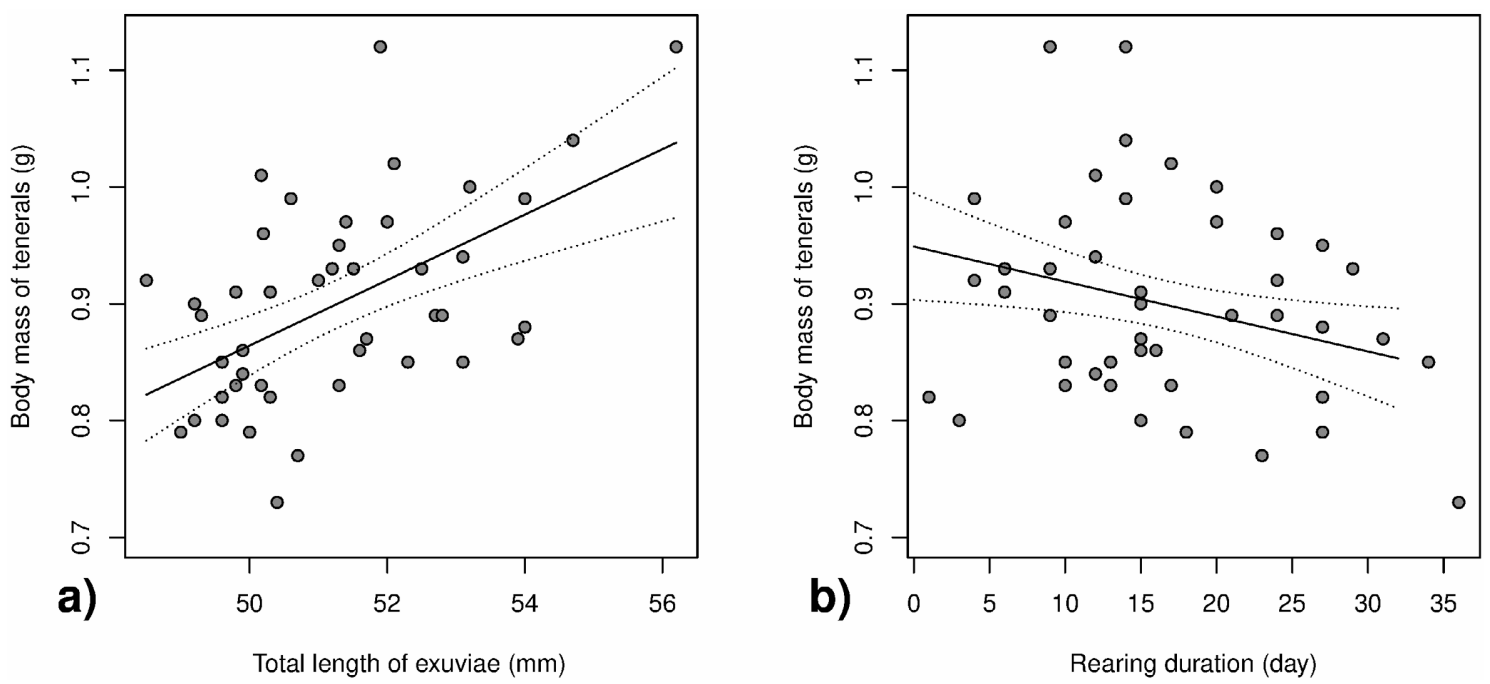

Fig. 4. Linear relationships between body mass of teneral adults of $A$. imperator and (a) total length of exuviae and (b) duration of rearing. Dotted lines are the $95 \%$ confidence intervals (see Table 3 for details). 

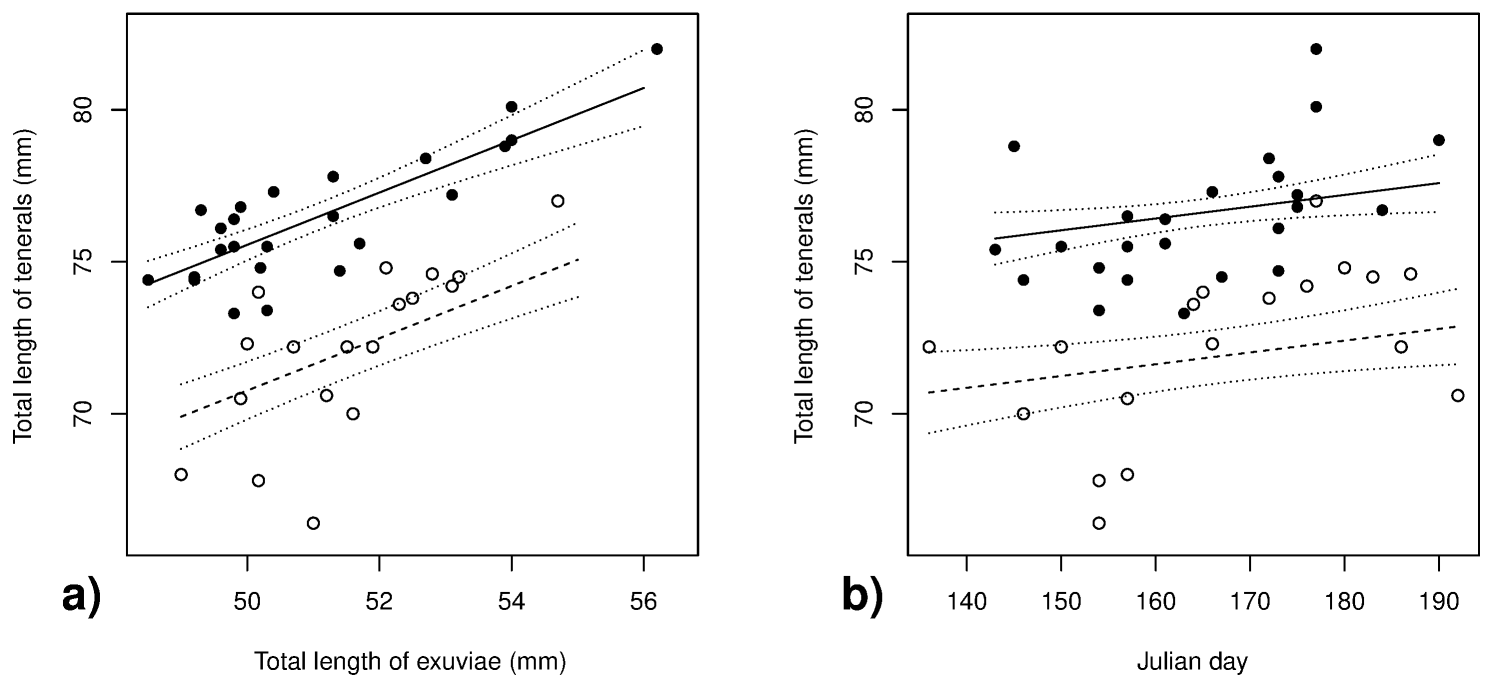

Fig. 5. Linear relationships between total length of teneral adults of $A$. imperator and (a) total length of exuviae and (b) the date of emergence in Julian days. Open dots represent females $(n=18)$ and filled dots males $(n=25)$. Dotted lines are the $95 \%$ confidence intervals (see Table 3 for details).

this study reveals new insights into the biometry of the large dragonfly Anax imperator.

A strong relationship was found between total length of exuviae and teneral adults, which indicate that larval conditions affected adult size. Maturation in odonates occurs between emergence and reproduction, during which individuals feed away from the ponds and become sexually mature (Tyagi, 2007). After maturation, adults caught near ponds were significantly longer and heavier than reared teneral adults. The significant growth in length during maturation is probably due to unfolding and/or stretching of abdominal intersegmental membranes. During this period, body mass of the females studied increased by an average of $39 \%$, while males showed only a slight gain in mass. A previous study also reports similar results for several species of dragonflies, with even a loss of mass in males in some species. The greater increase in body mass of females is probably due to the development of ovaries and stronger thoracic muscles (compared to males) to maintain flight performance (Anholt et al., 1991).

Females were significantly heavier than males, but rely on the same area of wing for flying. Nevertheless, this higher wing loading is not necessarily a significant disadvantage for females, since unlike males, they do not need to fly for long periods of time or fight.

For both sexes, differences in the body size and mass of teneral adults and mature adults could be explained by a better survival rate of the larger individuals that are generally fitter and have more energy reserves to get over the maturation period (Marden \& Rowan, 2000; Stoks \& Córdoba-Aguilar, 2012). However, no similar increase was found in wing length of teneral and mature adults and the increase in body length and mass should be therefore attributed to feeding.

Contrary to previous studies on odonates (review by Corbet, 1999; Falck \& Johansson, 2000), the body length

Table 4. Results of two-way analyses testing the effect of age, sex and their interaction on three traits of adult Anax imperator.

\begin{tabular}{lcccc}
\hline Variable & Method & Age & Sex & Interaction \\
\hline Total length & Two-way ANOVA & Matures $>$ Tenerals & Males $>$ Females & No \\
& & $(\mathrm{F}=36.5, \mathrm{P}<0.001)$ & $(\mathrm{F}=124, \mathrm{P}<0.001)$ & $(\mathrm{F}=0.578, \mathrm{P}=0.449)$ \\
Hind wing length & Two-way ANOVA & No difference & No difference & No \\
& & $(\mathrm{F}=0.248, \mathrm{P} 0.619)$ & $(\mathrm{F}=0.520, \mathrm{P}=0.472)$ & $(\mathrm{F}=3.45, \mathrm{P}=0.066)$ \\
Body mass & Scheirer-Ray-Hare & Matures $>$ Tenerals & No difference & Yes \\
& & $(\mathrm{H}=45.6, \mathrm{P}<0.001)$ & $(\mathrm{H}=3.01, \mathrm{P}=0.083)$ & $(\mathrm{H}=7.94, \mathrm{P}=0.005)$ \\
\hline
\end{tabular}

Table 5. Results of the models testing the associations between total length or body mass of $A$. imperator and the date sampled in Julian days. Regressions were done on both sexes of mature individuals. Variables were selected using AIC. Regression coefficient $\left(R^{2}\right)$ is given for the final model using adjustment when more than one variable was selected. Model $p$-values below the 0.05 threshold are given in bold.

\begin{tabular}{|c|c|c|c|c|c|c|}
\hline Age and sex & Response & Selected variable & Estimate \pm SE & Estimate $p$-value & Model p-value & Model $\mathrm{R}^{2}$ \\
\hline Mature males & Body mass & $\begin{array}{l}\text { Julian Day } \\
\text { Julian Day }\end{array}$ & $\begin{array}{r}0.020 \pm 0.010 \\
-0.000 \pm 0.000\end{array}$ & $\begin{array}{l}0.051 \\
0.068\end{array}$ & 0.004 & 0.260 \\
\hline Mature females & Body mass & none & - & - & - & - \\
\hline Mature males & Total length & $\begin{array}{l}\text { Julian Day } \\
\text { Julian Day² }\end{array}$ & $\begin{array}{r}0.558 \pm 0.283 \\
-0.001 \pm 0.001\end{array}$ & $\begin{array}{l}0.058 \\
0.054\end{array}$ & 0.104 & 0.085 \\
\hline Mature females & Total length & $\begin{array}{l}\text { Julian Day } \\
\text { Julian Day }\end{array}$ & $\begin{array}{r}0.156 \pm 0.065 \\
-0.002 \pm 0.001\end{array}$ & $\begin{array}{l}0.061 \\
0.072 \\
\end{array}$ & 0.046 & 0.282 \\
\hline
\end{tabular}



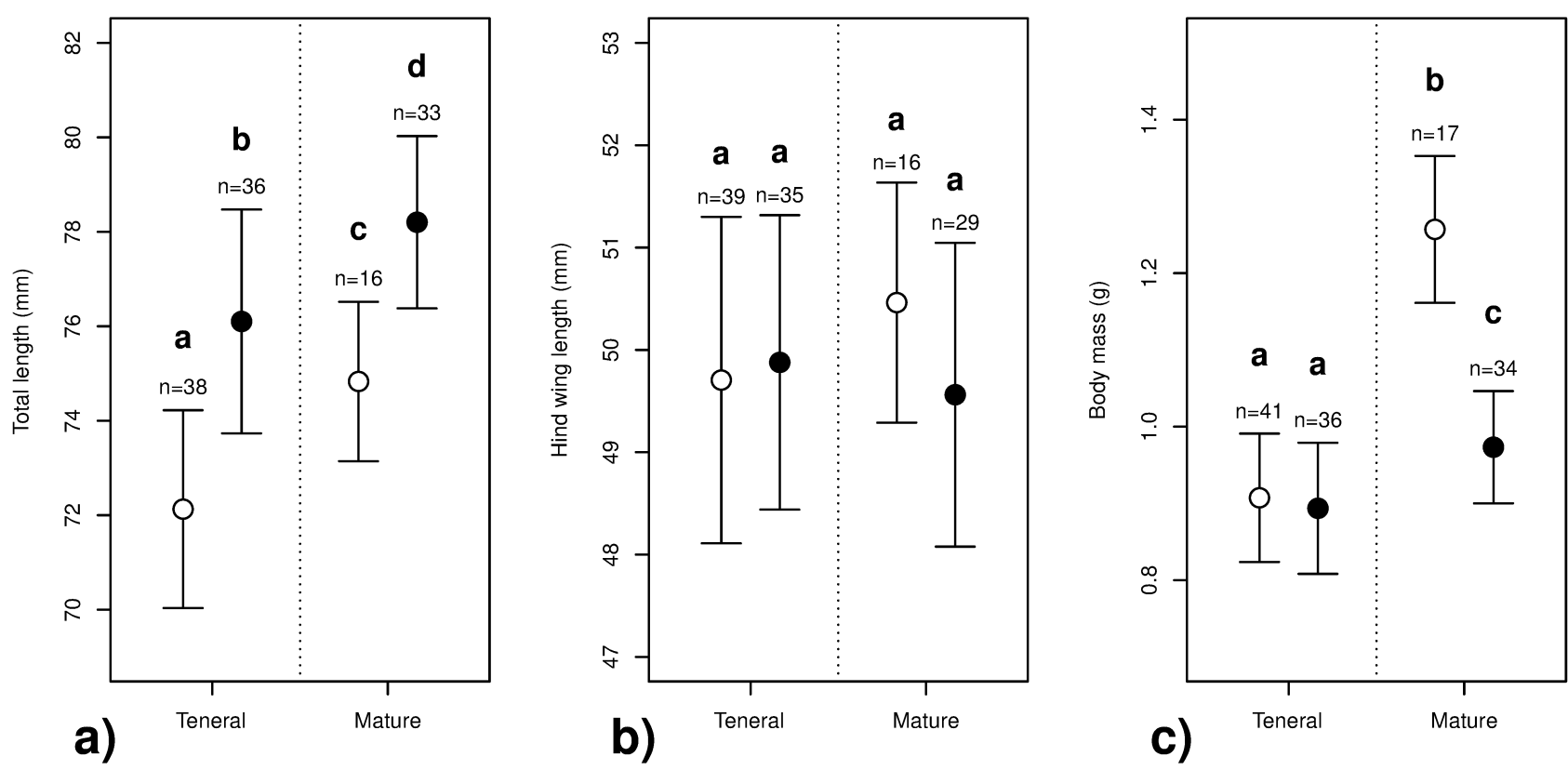

Fig. 6. Comparison of the traits of reared teneral and mature adults of each sex caught in the field. Females are represented by open dots and males by filled dots. Values plotted are the means \pm SD: total body length (a), total length of right hind wing (b) and total body mass (c). Letters indicate significant differences in post-hoc analyses $(\alpha=0.05)$.

and mass of teneral adults of $A$. imperator of both sexes were greater the later they emerged. This could be due to the fact that individuals emerging late in the season have more time to grow before emergence.

For mature adults, the maximum total length or mass was recorded near the end of the flying season. The increase in body length and mass at the beginning of the season can be related to the fact, that the individuals that emerged early will probably be small and light adults. The recorded increase in mass in males could also be explained by a longer survival of the heavier males (Waller \& Svensson, 2017), which are therefore predominant at the end of the flying season. They need to fight and fly for a long time before mating (Jödicke, 1997), which probably results in the death of the weaker individuals.

After the recorded maximum, the prevalence of small and light individuals at the end of the flying period could be explained by harsher environmental conditions, such as a lower food availability.

Sexual Size Dimorphism (SSD) in dragonflies can be either male- or female-biased, but there is a tendency for male-biased SSD in territorial species and female-biased SSD in non-territorial species (Serrano-Meneses et al., 2008). In this study, although larvae of females were longer than those of males, both sexes had the same body mass at emergence and adult males were significantly longer than females. This male-biased SSD in A. imperator is consistent with the territorial behaviour of this species, but not with Serrano-Meneses et al. (2007) results in northwestern Spain, where adult females of $A$. imperator were significantly longer $(72 \pm 2 \mathrm{~mm})$ than males $(69 \pm 1$ $\mathrm{mm})$ at emergence. The difference in total length could be explained by Bergman's rule for males, since the present study in northwestern France was conducted at a higher latitude, which should result in larger individuals. However, this rule does not account for the similar sizes of the females in both studies.

Intraspecific competition between voltinism groups can affect larval mortality (Crowley et al., 1987). In dragonflies, voltinism greatly depends on temperature and thus also on latitude (Corbet et al., 2006). In this study, measurements of the last larval instars seem to follow a unimodal distribution for each stadium with no indication of different classes of voltinism. Either the larvae studied were all univoltine although expected to be at least partly semivoltine in Normandy (extrapolated from Corbet et al., 2006), or differences in voltinism did not affect head width in the last three larval instars.

Measurements of head width and wing pad length of larvae proved to be a very efficient way of discriminating between last larval instars and allowed comparison with data from other studies carried out at different latitudes

Table 6. Published values of larval head widths (in $\mathrm{mm}$ ) for the four last larval instars of $A$. imperator. Lines are ordered according to latitude.

\begin{tabular}{|c|c|c|c|c|c|c|}
\hline Reference & Country & Value & F0 & $\mathrm{F}-1$ & $\mathrm{~F}-2$ & $\mathrm{~F}-3$ \\
\hline Corbet (1955) & England $\left(51^{\circ} \mathrm{N}\right)$ & 1 larva & 9.0 & 8.1 & 7.2 & 6.2 \\
\hline Minot et al. (present data) & France $\left(49^{\circ} \mathrm{N}\right)$ & Mean \pm SD & $8.7 \pm 0.2$ & $7.2 \pm 0.2$ & $5.9 \pm 0.2$ & $5.0 \pm 0.2$ \\
\hline Portmann (1921) & Switzerland $\left(47^{\circ} \mathrm{N}\right)$ & NA & 9.0 & 7.3 & 6.0 & NA \\
\hline Robert (1958) & Switzerland & Min-Max & $8.5-9.2$ & $6.9-7.7$ & $5.7-6.1$ & $4.9-5.5$ \\
\hline Lamelas-Lopez et al. (2017) & Spain $\left(38^{\circ} \mathrm{N}\right)$ & Mean \pm SD & $9.6 \pm 0.3$ & $8.8 \pm 0.3$ & $7.9 \pm N A$ & $6.9 \pm 0.3$ \\
\hline
\end{tabular}



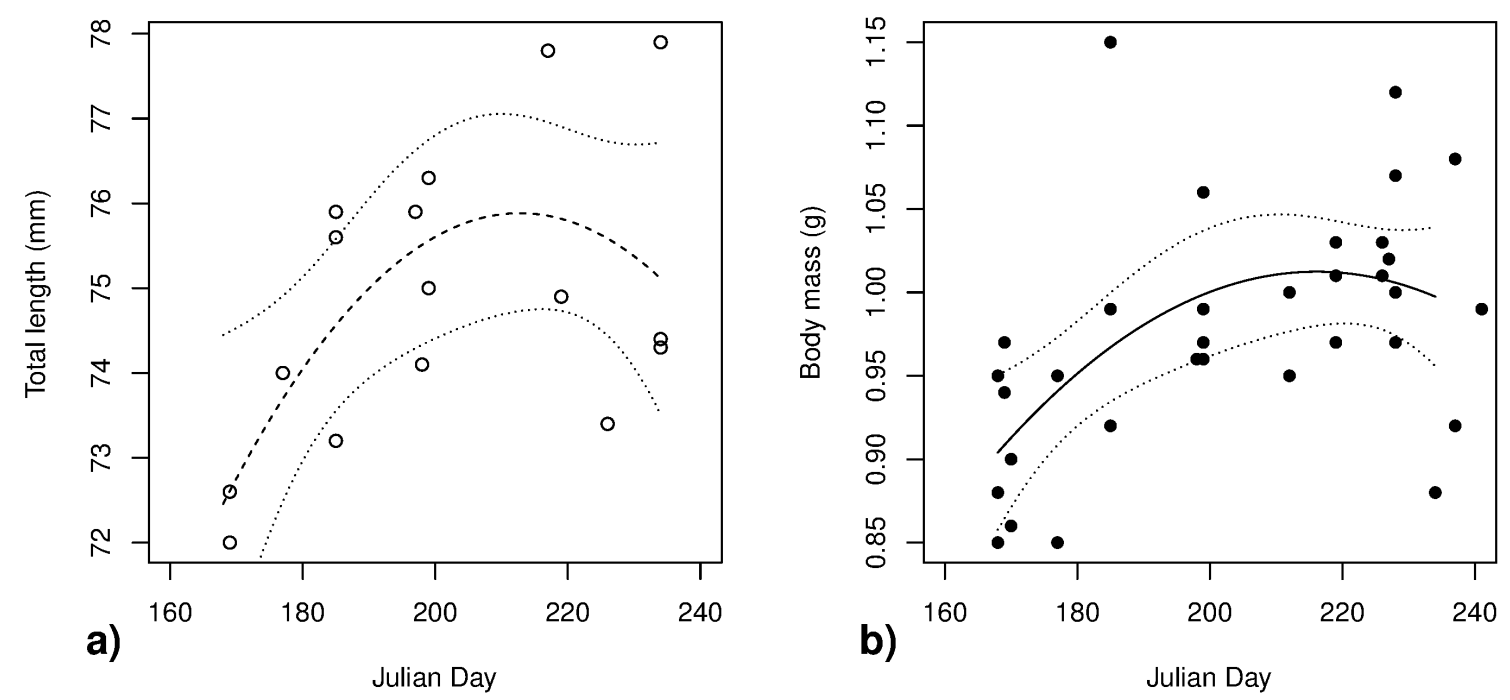

Fig. 7. Regressions between total length of mature females (a) and body mass of mature males (b) of Anax imperator recorded on different dates in Julian days. Dotted lines are the $95 \%$ confidence intervals.

(Table 6). Thresholds and mean values of larval head width were smaller in this study than in those recorded in England (Corbet, 1955) and increase in size between instars was higher. This difference in larval length and growth can be explained by differences in latitude and climate in Normandy and England. It is surprising that the comparison of the mean wing length of adults in the two regions revealed no significant difference given that the sizes of the larvae were very different. It would be interesting to compare other traits than wing length, but unfortunately, no other data is available. Larval measurements from Switzerland are very similar to our values. Although situated at a slightly lower latitude, the sites sampled in Switzerland are located at higher altitudes, where probably the mean temperatures are similar to those in Normandy. In the Azores, Lamelas-Lopez et al. (2017) report larger means for head width and lower growth rates, similar to those of Corbet (1955) in England. If not a misinterpretation of the published data from the Azores, this result is quite unexpected and difficult to explain according to Bergmann's rule which would predict smaller larvae and faster development at lower latitudes. This highlights the lack of data on odonate traits throughout the world and the need to better understand variations in larval development at different latitudes.

In line with previous results on Aeshna cyanea Müller, 1764 (Goretti et al., 2001), significant difference was found between the total length of last instar larvae and their exuviae. More surprisingly, an increase in total length within the metamorphosis stages of the last instar was highlighted. Since it is not possible for sclerites to change size, except during moulting, they overlap in the early stages of metamorphosis and gradual stretching of infolded membranes allows for an increase in the total larval length. It is therefore important to take the stages of metamorphosis into account in studies using the total length.

Overall, our results highlight the importance of taking into account the whole life cycle when studying the fitness, behaviour and dispersal capacity of large dragonflies. In A. imperator, we found a relationship between larval and teneral adult traits. Further investigation is needed to fully understand the voltinism and mechanisms of larval development at different latitudes. Nevertheless, we can already state that a lot of the variability depends on climatic conditions or environmental perturbations. Emerging theories connecting traits to the ecological roles of individuals now enable the prediction of species abundance and community assembly (McGill, 2006; Laughlin et al., 2012), and open up new perspectives for trait-based-ecology. Hence, trait studies are a crucial background information for understanding variations at local and larger scales and enhance further investigations on dispersal and population dynamics.

ACKNOWLEDGEMENTS. We would like to thank the Seine-Normandy Water Agency for its financial contribution to the research project CROSS. M. Minot was supported by a Ph.D. grant provided by the French Ministry of Higher Education and Research through the Normandy's Doctoral School of Integrative Biology, Health and Environment (EdN BISE 497, Rouen University). M. Aubert and A. Husté (ECODIV URA IRSTEA/EA 1293) were the Ph.D. co-supervisors. Thanks are due to H. Terrones for his help during the laboratory work and field collections. We also thank L. Mundell and A.F.G. Dixon for reviewing the English and our two anonymous reviewers for their constructive comments to improve the manuscript.

\section{REFERENCES}

Anholt B.R., Marden J.H. \& JenKins D.M. 1991: Patterns of mass gain and sexual dimorphism in adult dragonflies (Insecta: Odonata). - Can. J. Zool. 69: 1156-1163.

Arambourou H., Sanmartín-Villar I. \& Stoks R. 2017: Wing shape-mediated carry-over effects of a heat wave during the larval stage on post-metamorphic locomotor ability. - Oecologia 184: 279-291.

ARnqvist G., Rowe L., KRUPA J.J. \& SiH A. 1996: Assortative mating by size: a meta-analysis of mating patterns in water striders. -Evol. Ecol. 10: 265-284. 
BENKE A.C. 1970: A method for comparing individual growth rates of aquatic insects with special reference to the Odonata. - Ecology 51: 328-331.

Bergelson J.M. 1985: A mechanistic interpretation of prey selection by Anax junius larvae (Odonata: Aeschnidae). — Ecology 66: 1699-1705.

BlAnCKenhorn W.U. 2000: The evolution of body size: what keeps organisms small? - Quart. Rev. Biol. 75: 385-407.

BLoIs C. 1985: The larval diet of three anisopteran (Odonata) species. - Freshw. Biol. 15: 505-514.

Blois C. \& Cloarec A. 1985: Influence of experience on prey selection by Anax imperator larvae (Aeschnidae - Odonata). —Z. Tierpsychol. 68: 303-312.

Blois-Heulin C. 1990a: Influence of prey densities on prey selection in Anax imperator larvae (Odonata: Aeshnidae). - Aquat. Insects 12: 209-217.

Blois-Heulin C. 1990b: Familiarization and spatial distribution in Anax imperator larvae (Aeshnidae, Odonata). - Ethol. Ecol. Evol. 2: 335-344.

Brochard C., Groenendijk C., der Ploeg E.V. \& Termatt T. 2012: Photographic Guide to Larval Exuviae of Dragonflies. KNNV Publishing, Zeist, 320 pp. [in Dutch].

Burke R.J., Fitzsimmons J.M. \& KerR J.T. 2011: A mobility index for Canadian butterfly species based on naturalists' knowledge. - Biodiv. Conserv. 20: 2273-2295.

CALVert P.P. 1934: The rates of growth, larval development and seasonal distribution of dragonflies of the genus Anax (Odonata: Aeshnidae). — Proc. Am. Philos. Soc. 73: 1-70.

ChOwn S.L. \& Gaston K.J. 2010: Body size variation in insects: a macroecological perspective. - Biol. Rev. 85: 139-169.

Conrad K.F., Willson K.H., Whitfield K., Harvey I.F., Thomas C.J. \& SherRATt T.N. 2002: Characteristics of dispersing Ischnura elegans and Coenagrion puella (Odonata): age, sex, size, morph and ectoparasitism. - Ecography 25: 439-445.

CoRBET P.S. 1955: The immature stages of the emperor dragonfly, Anax imperator Leach (Odonata: Aeshnidae). — Entomol. Gaz. 6: 189-197.

CoRbet P.S. 1957: The life-history of the emperor dragonfly Anax imperator Leach (Odonata: Aeshnidae). - J. Anim. Ecol. 26: $1-69$.

Corbet P.S. 1999: Dragonflies: Behaviour and Ecology of Odonata. Harley Books, Colchester, 864 pp.

Corbet P.S., Suhling F. \& Soendgerath D. 2006: Voltinism of Odonata: a review. - Int. J. Odonatol. 9: 1-44.

Crowley P.H., Dillon P.M., Johnson D.M. \& Watson C.N. 1987: Intraspecific interference among larvae in a semivoltine dragonfly population. - Oecologia 71: 447-456.

CRUMrine P.W. 2010: Body size, temperature, and seasonal differences in size structure influence the occurrence of cannibalism in larvae of the migratory dragonfly, Anax junius. - Aquat. Ecol. 44: 761-770.

De Block M. \& R. Stoks 2003: Adaptive sex-specific life history plasticity to temperature and photoperiod in a damselfly. $-J$. Evol. Biol. 16: 986-995.

Dijkstra K.-D.B. \& Lewington R. 2006: Field Guide to the Dragonflies of Britain and Europe. British Wildlife, Rotherwick, $320 \mathrm{pp}$.

Enquist B.J., Norberg J., Bonser S.P., Violle C., Webb C.T., Henderson A., Sloat L.L. \& Savage V.M. 2015: Chapter nine - scaling from traits to ecosystems: developing a general trait driver theory via integrating trait-based and metabolic scaling theories. In Pawar S., Woodward G. \& Dell A.I. (eds): $A d$ vances in Ecological Research. Academic Press, San Diego, pp. 249-318.
Falck J. \& Johansson F. 2000: Patterns in size, sex ratio and time at emergence in a south Swedish population of Sympetrum sanguineum (Odonata). - Aquat. Insects 22: 311-317.

Fardila D., Kelly L.T., Moore J.L. \& McCarthy M.A. 2017: A systematic review reveals changes in where and how we have studied habitat loss and fragmentation over 20 years. - Biol. Conserv. 212: 130-138.

FAurby S. \& ARaúJo M.B. 2017: Anthropogenic impacts weaken Bergmann's rule. - Ecography 40: 683-684.

Ferreras-Romero M. \& Corbet P.S. 1999: The life cycle of $C o r-$ dulegaster boltonii (Donovan, 1807) (Odonata: Cordulegastridae) in the Sierra Morena Mountains (southern Spain). - Hydrobiologia 405: 39-48.

Folsom T.C. \& Collins N.C. 1984: The diet and foraging behavior of the larval dragonfly Anax junius (Aeshnidae), with an assessment of the role of refuges and prey activity. - Oikos 42: 105-113.

Goretti E., Ceccagnoli D., La Porta G. \& Di Giovanni M.V. 2001: Larval development of Aeshna cyanea (Müller, 1764) (Odonata: Aeshnidae) in Central Italy. - Hydrobiologia 457: $149-154$.

Grether G.F. 1996: Sexual selection and survival selection on wing coloration and body size in the rubyspot damselfly Hetaerina americana. - Evolution 50: 1939-1948.

Haddad N.M., Brudvig L.A., Clobert J., Davies K.F., Gonzalez A., Holt R.D., Lovejoy T.E., Sexton J.O., Austin M.P., ColLINS C.D ET AL. 2015: Habitat fragmentation and its lasting impact on Earth's ecosystems. - Sci. Advan. 1: e1500052, 9 pp.

Harrison X.A., Blount J.D., Inger R., Norris D.R. \& Bearhop S. 2011: Carry-over effects as drivers of fitness differences in animals. - J. Anim. Ecol. 80: 4-18.

Heidemann H. \& Seidenbusch R. 2002: Larves et Exuvies des Libellules de France et d'Allemagne. Société Française d'Odonatologie, Bois-d'Arcy, 416 pp.

Heise B.A., Flannagan J.F. \& Galloway T.D. 1988: Production of Hexagenia limbata (Serville) and Ephemera simulans Walker (Ephemeroptera) in Dauphin Lake, Manitoba, with a note on weight loss due to preservatives. - Can. J. Fish. Aquat. Sci. 45: 774-781.

HoNĚK A. 1993: Intraspecific variation in body size and fecundity in insects: a general relationship. — Oikos 66: 483-492.

JöDICKE R. 1997: Tagesperiodik der Flugaktivität von Anax imperator Leach (Anisoptera: Aeshnidae). — Libellula 16: 111129.

JohANSSON F. 2003: Latitudinal shifts in body size of Enallagma cyathigerum (Odonata). - J. Biogeogr. 30: 29-34.

KLECKA J. \& BouKaL D.S. 2013: Foraging and vulnerability traits modify predator-prey body mass allometry: freshwater macroinvertebrates as a case study. - J. Anim. Ecol. 82: 10311041.

Kremer C.T., Williams A.K., Finiguerra M., Fong A.A., Kellerman A., Paver S.F., Tolar B.B. \& Toscano B.J. 2017: Realizing the potential of trait-based aquatic ecology: New tools and collaborative approaches. - Limnol. Oceanogr. 62: 253-271.

Lailvaux S.P. \& HusaK J.F. 2014: The life history of whole-organism performance. - Quart. Rev. Biol. 89: 285-318.

Lamelas-López L., Florencio M., Borges P.A.V. \& Cordero-RiVERA A. 2017: Larval development and growth ratios of Odonata of the Azores. - Limnology 18: 71-83.

LANCASTER J. \& Downes B.J. 2017: Dispersal traits may reflect dispersal distances, but dispersers may not connect populations demographically. - Oecologia 184: 171-182.

Laughlin D.C., Joshi C., van Bodegom P.M., Bastow Z.A. \& Fulé P.Z. 2012: A predictive model of community assembly 
that incorporates intraspecific trait variation. - Ecol. Lett. 15 1291-1299.

Leuven R.S.E.W., Brock T.C.M. \& van Druten H.A.M. 1985 Effects of preservation on dry- and ash-free dry weight biomass of some common aquatic macro-invertebrates. - Hydrobiologia 127: 151-159.

Litchman E., De T. Pinto P., Klausmeier C.A., Thomas M.K. \& YoshiYama K. 2010: Linking traits to species diversity and community structure in phytoplankton. - Hydrobiologia $\mathbf{6 5 3}$ : $15-28$.

Mangiafico S. 2017: rcompanion: Functions to Support Extension Education Program Evaluation. R Package Ver. 1.5. 0 . The Comprehensive R Archive Network. URL: https://cran.rproject.org/web/packages/rcompanion/

MARDEN J.H. \& RowAN B. 2000: Growth, differential survival, and shifting sex ratio of free-living Libellula pulchella (Odonata: Libellulidae) dragonflies during adult maturation. - Ann. Entomol. Soc. Am. 93: 452-458.

McCAuley S.J. 2005: Relationship between habitat distribution, growth rate, and plasticity in congeneric larval dragonflies. Can. J. Zool. 83: 1128-1133.

McGill B., Enquist B., Weiner E. \& Westoby M. 2006: Rebuilding community ecology from functional traits. - Trends Ecol. Evol. 21: 178-185.

McGill B.J. 2006: A renaissance in the study of abundance. Science 314: 770-772.

Méthot G., Hudon C., Gagnon P., Pinel-Alloul B., Armellin A. \& PoIRIER A.-M.T. 2012: Macroinvertebrate size-mass relationships: how specific should they be? - Freshw. Sci. 31: 750-764.

Michiels N.K. \& Dhondt A.A. 1991: Characteristics of dispersal in sexually mature dragonflies. - Ecol. Entomol. 16: 449-459.

PecheniK J.A. 2006: Larval experience and latent effects - metamorphosis is not a new beginning. - Integr. Compar. Biol. 46: 323-333.

Pinheiro J., Bates D., DebRoy S., Sarkar D. \& R Core Team 2008: nlme: Linear and Nonlinear Mixed Effects Models. $R$ Package Ver. 3.1-137. URL: https://cran.r-project.org/web/ packages/nlme/

Portmann A. 1921: Die Odonaten der Umgebung von Basel: Beitrag zur biologischen Systematik der mitteleuropäischen Libellen. Thesis, Universität Basel.

Powney G., Brooks S., Barwell L., Bowles P., Fitt R., Pavitt A., Spriggs R. \& IsAaC N. 2014: Morphological and geographical traits of the British Odonata. - Biodiv. Data J. 2: e1041, 12 pp.

R CoRe TeAm 2017: A Language and Environment for Statistical Computing. Version 3.4.2. R Foundation for Statistical Computing, Vienna. URL: https://cran.r-project.org/src/base/R-3/R3.4.2.tar.gz

Relyea R.A. 2012: New effects of Roundup on amphibians: predators reduce herbicide mortality; herbicides induce antipredator morphology. - Ecol. Appl. 22: 634-647.

Robert P.-A. 1958: Les Libellules: Odonates. Delachaux \& Niestlé, Neuchâtel \& Paris.

Rundle S.D., Bilton D.T., Aвbott J.C. \& Foggo A. 2007: Range size in North American Enallagma damselflies correlates with wing size. - Freshw. Biol. 52: 471-477.

SAMEJIMA Y. \& TsuBAKI Y. 2010: Body temperature and body size affect flight performance in a damselfly. - Behav. Ecol. Sociobiol. 64: 685-692.

Santos N.C.L. dos, de Santana H.S., Ortega J.C.G., Dias R.M., Stegmann L.F., da Silva Araújo I.M., Severi W., Bini L.M., Gomes L.C. \& Agostinho A.A. 2017: Environmental filters predict the trait composition of fish communities in reservoir cascades. - Hydrobiologia 802: 245-253.
SEKAR S. 2012: A meta-analysis of the traits affecting dispersal ability in butterflies: can wingspan be used as a proxy? $-J$. Anim. Ecol. 81: 174-184.

Serrano-Meneses M.-A., Azpilicueta-Amorín M., SzéKely T. \& Córdoba-Aguilar A. 2007: The development of sexual differences in body size in Odonata in relation to mating systems. - Eur. J. Entomol. 104: 453-458.

Serrano-Meneses M.A., Córdoba-Aguilar A., AzpilicuetaAmorín M., GonzÁlez-Soriano E. \& SzéKely T. 2008: Sexual selection, sexual size dimorphism and Rensch's rule in Odonata. - J. Evol. Biol. 21: 1259-1273.

Slade E.M., Merckx T., Riutta T., Bebber D.P., Redhead D., RioRdAN P. \& MACDONALD D.W. 2013: Life-history traits and landscape characteristics predict macro-moth responses to forest fragmentation. - Ecology 94: 1519-1530.

Sniegula S., Golab M.J. \& Johansson F. 2016: A large-scale latitudinal pattern of life-history traits in a strictly univoltine damselfly. - Ecol. Entomol. 41: 459-472.

Sokolovska N., Rowe L. \& Johansson F. 2000: Fitness and body size in mature odonates. - Ecol. Entomol. 25: 239-248.

Stav G., Blaustein L. \& Margalit Y. 2000: Influence of nymphal Anax imperator (Odonata: Aeshnidae) on oviposition by the mosquito Culiseta longiareolata (Diptera: Culicidae) and community structure in temporary pools. - J. Vector Ecol. $\mathbf{2 5}$ : 190-202.

Stoks R. \& CóRdoba-Aguilar A. 2012: Evolutionary ecology of Odonata: a complex life cycle perspective. - Annu. Rev. Entomol. 57: 249-265.

Stoks R. \& De Block M. 2011: Rapid growth reduces cold resistance: evidence from latitudinal variation in growth rate, cold resistance and stress proteins. - PLOS ONE 6: e16935, 6 pp.

Stoks R. \& McPeек M.A. 2003: Predators and life histories shape Lestes damselfly assemblages along a freshwater habitat gradient. - Ecology 84: 1576-1587.

Suhling F., Müller O. \& Martens A. 2014: The dragonfly larvae of Namibia (Odonata). — Libellula (Suppl.) 13: 5-106.

Swaegers J., Janssens S.B., Ferreira S., Watts P.C., Mergeay J., McPeek M.A. \& Stoks R. 2014: Ecological and evolutionary drivers of range size in Coenagrion damselflies. - J. Evol. Biol. 27: 2386-2395.

Tarboton W.R. \& Tarboton M. 2015: A Guide to the Dragonflies and Damselfties of South Africa. Penguin Random House South Africa, Cape Town, 216 pp.

TaYlor P.D. \& MerRiam G. 1995: Wing morphology of a forest damselfly is related to landscape structure. - Oikos 73: 43-48.

THOMPSON D.J. \& Fincke O.M. 2002: Body size and fitness in Odonata, stabilising selection and a meta-analysis too far? Ecol. Entomol. 27: 378-384.

TÜZÜN N. \& STOKs R. 2018: Pathways to fitness: carryover effects of late hatching and urbanisation on lifetime mating success. - Oikos 127: 949-959.

Tyagi B.K. 2007: Odonata. Biology of Dragonflies. Scientific Publishers, Jodhpur, $366 \mathrm{pp}$

Violle C., Navas M.-L., Vile D., Kazakou E., Fortunel C., HumMEL I. \& GARNIER E. 2007: Let the concept of trait be functional! - Oikos 116: 882-892.

SCHILler D. vON \& Solimini A.G. 2005: Differential effects of preservation on the estimation of biomass of two common mayfly species. - Arch. Hydrobiol. 164: 325-334.

WALLER J.T. \& SVENsSON E.I. 2017: Body size evolution in an old insect order: no evidence for Cope's Rule in spite of fitness benefits of large size. - Evolution 71: 2178-2193.

Watt C., Mitchell S. \& SAlewski V. 2010: Bergmann's rule; a concept cluster? - Oikos 119: 89-100. 
Wikelski M., Moskowitz D., Adelman J.S., Cochran J., Wilcove D.S. \& MAY M.L. 2006: Simple rules guide dragonfly migration. - Biol. Lett. 2: 325-329.

Zeuss D., Brunzel S. \& BRANDL R. 2017: Environmental drivers of voltinism and body size in insect assemblages across Europe. - Glob. Ecol. Biogeogr. 26: 154-165.
Zuur A.F., Ieno E.N., Walker N.J., SAVeliev A.A. \& Smith G.M. 2009: Mixed Effects Models and Extensions in Ecology with R. Springer, New York, $574 \mathrm{pp}$.

Zuur A.F., Hilbe J.M. \& Ieno E.N. 2015: A Beginner's Guide to GLM and GLMM with R: A Frequentist and Bayesian Perspective for Ecologists. Highland Statistics Ltd., Newburgh, 256 pp.

Received November 29, 2018; revised and accepted July 19, 2019 Published online September 10, 2019

Stage (1) No external sign of metamorphosis; larvae in resting state; cuticle teneral or hard.

Stage (2) Compound eyes approaching towards the mid-dorsum of the head but more than $0.25 \mathrm{~mm}$ apart.

Stage (3) Eyes less than $0.25 \mathrm{~mm}$ apart but not touching mesially.

Stage (4) Eyes touching mesially; labium larval.

Stage (5) Tissues of labium in process of retracting through sheath of larval prementum.

Stage (6) Labium of adult fully-formed and retracted, lying within sheath of larval postmentum.
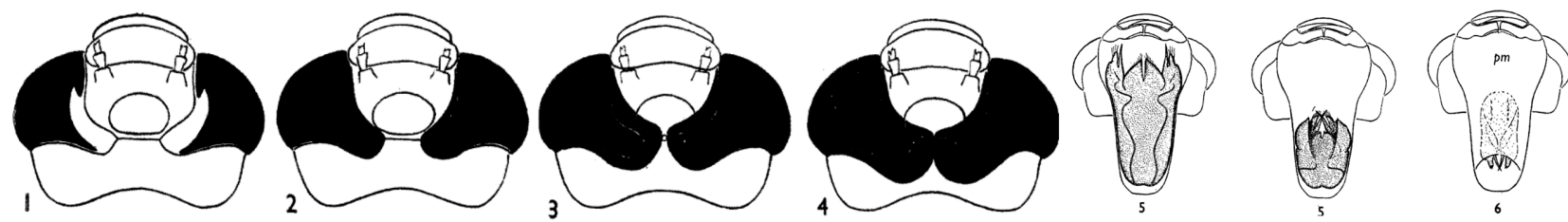

Heads of final instar larvae to illustrate stages 1-6 of metamorphosis. 1-4, dorsal view; 5-6, ventral view. $p m$, larval prementum.

Fig. A1. Definition of the 6 stages of metamorphosis (Corbet, 1957).

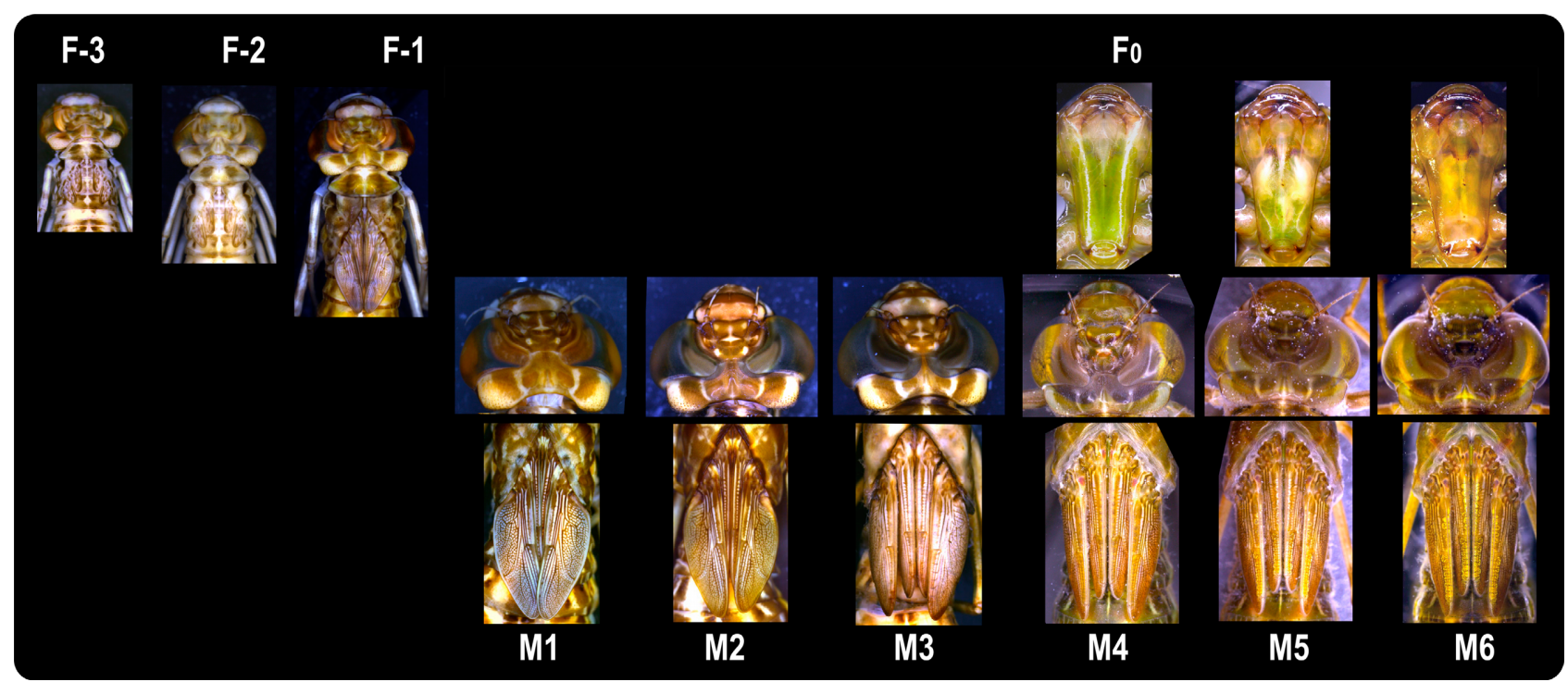

Fig. A2. Illustrations of the morphological changes during larval growth. (Pictures F-3 to M3: Larvae from collection; M4 to M6 reared larva). 


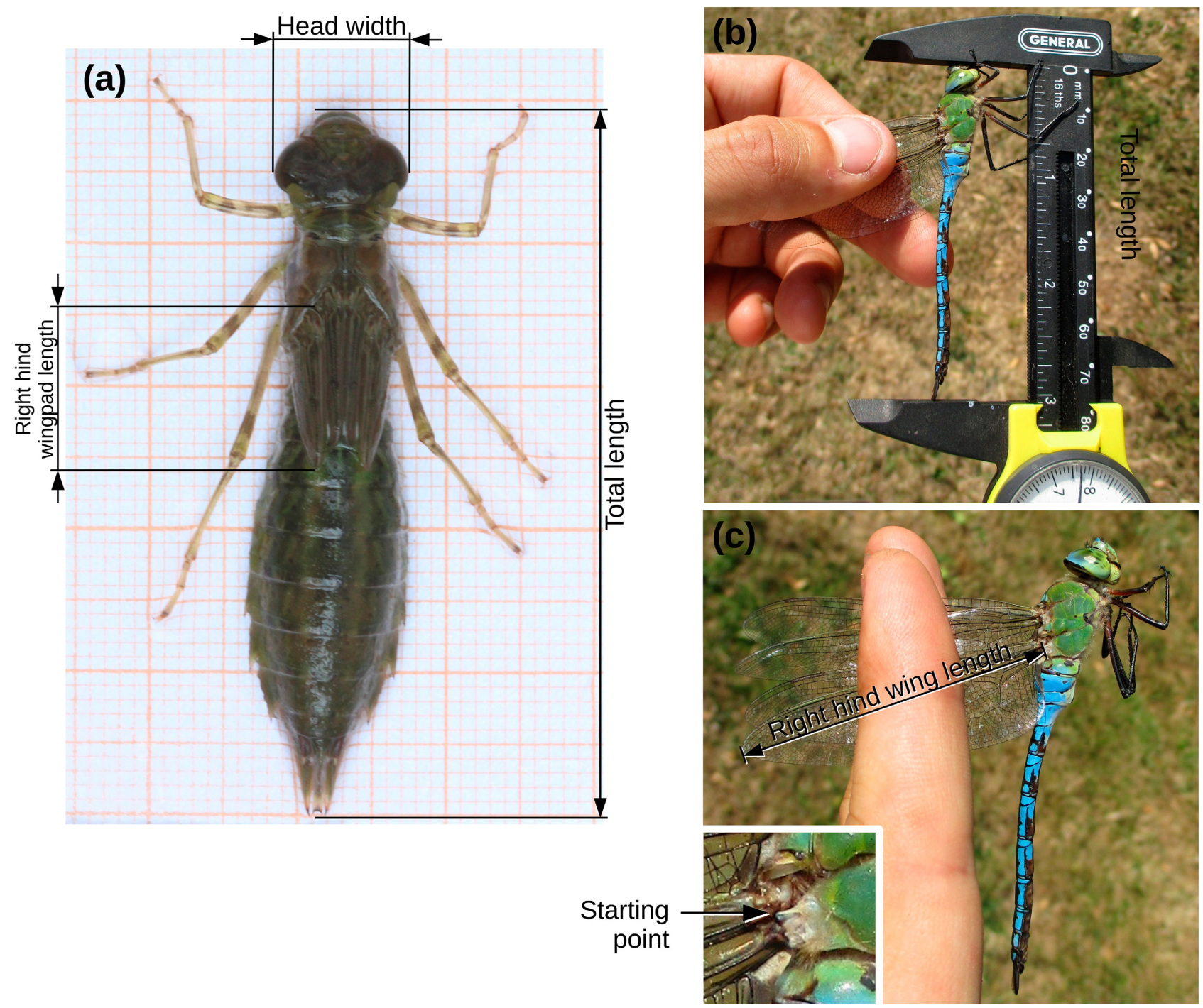

Fig. A3. Mesurement method used for physical traits of larvae (a) and adults (b, c) Anax imperator. 